ISSN : $1225-9918$

\title{
Effect of Trans-unsaturated Fatty Acid on Serum Lipid Levels in Mice
}

Sun Nyoung $\mathrm{Yu}^{1+}$, Jeong Bin $\mathrm{Ahn}^{2^{+}}$, EunYoung Park ${ }^{3^{+}}$, Sun Jung $\mathrm{Lee}^{4^{+}}$, Min Gi Tak ${ }^{5^{\dagger}}$, Kwang Youn $\mathrm{Kim}^{1}$, Sang Hun Kim${ }^{1}$, Ki Dae Kim ${ }^{6}$ and Soon Cheol Ahn*

${ }^{1}$ Department of Microbiology and Immunology, Pusan National University School of Medicine, Yangsan 626-870, Korea

${ }^{2}$ School of Nano-Bioscience and Chemical Engineering Ulsan National Institute of Science and Technology, Ulsan 689-798, Korea

${ }^{3}$ Department of Chemical Engineering College of Engineering, Pukyong University, Busan 608-737, Korea

${ }^{4}$ Department of Health Care Management, Catholic University of Pusan, Busan 609-757, Korea

${ }^{5}$ Department of Genetic Engineering College of Biotechnology and Biongineering, Sunkyunkwan University, Suwon 440-746, Korea

${ }^{6}$ DongNae Girls' High School, Busan 609-718, Korea

Received June 26, 2012 /Revised August 24, 2012 /Accepted August 24, 2012

\begin{abstract}
The purpose of this study was to investigate the effects of trans-unsaturated fatty acid (TFA), saturated fatty acid (SFA) and general unsaturated fatty acid (USFA) on serum lipid levels in ICR mice. Male ICR 8-week-old mice were divided into six groups; the control group (C) fed with normal diet, the TFA-1 group fed with 10\% trans-unsaturated fatty acid, the TFA- 2 group fed with $30 \%$ trans-unsaturated fatty acid, the TFA-3 group fed with 50\% trans-unsaturated fatty acid, the SFA group fed with $50 \%$ saturated fatty acid, and USFA group fed with $50 \%$ general unsaturated fatty acid. The serum total cholesterol of TFA-3 and SFA was higher than those of other fat groups and C. The serum triglyceride (TG) of TFA-3 and SFA showed the highest levels among all of diet groups. Also the serum HDL cholesterol levels of TFA-3 showed the lowest. LDL cholesterol and atherogenic indices (AI) were remarkedly increased in TFA-3 and SFA, as compared with other fat fed groups and C. Taken together with results, the TFA-3 group showed serum lipid levels similar to the SFA and different from the USFA. These results suggest that intake of high level of trans-unsaturated fatty acid increased serum triglyceride, LDL cholesterol and atherogenic indices, which may affect risk on serum lipid level for lipid metabolism syndrome.
\end{abstract}

Key words : Trans-unsaturated fatty acid, saturated fatty acid, general unsaturated fatty acid, serum lipid level, atherogenic indices

\section{서 론}

현대사회는 생활수준의 향상과 함께 서구화된 식생활로 인 해 간편하게 섭취할 수 있는 패스트푸드와 인스턴트식품의 소비량이 증가하고 있다. 이러한 식품들은 현재 전 세계 여러 나라의 주요한 사망 원인이 되는 한편, 비만[4,12], 심혈관계질 환[8,9], 당뇨[12] 등 성인병과 만성 퇴행성 질환 등의 요인으로 인식되고 있다. 패스트푸드 및 인스턴트식품에는 버터와 같은 포화지방산(saturated fatty acid)이 다량 함유된 동물성 지방 이나 마가린, 쇼트닝과 같은 트랜스지방이 많이 사용되고 있 기 때문이다[10].

포화지방산은 기본골격인 탄소분자에 수소분자가 빈틈없 이 결합된 포화상태의 지방산으로서 체내에서 필요에 따라 합성하여 사용하며 섭취한 음식물로 인해 획득한 과잉의 에 너지는 복부, 허벅지, 엉덩이 등의 피하에 지방으로 저장한 다. 불포화지방산(unsaturated fatty acid)의 경우, 단가 불포

*Corresponding author

Tel : +51-510-8092, Fax : +82-55-382-8090

E-mail : ahnsc@pusan.ac.kr

†Equally contributed
화 지방산과 다가 불포화지방산으로 구분되는데, 단가 불포 화 지방산은 혈액 내의 콜레스테롤 수치를 낮추어 심장질환, 뇌혈관 질환 등 동맥 경화성 질환의 발병위험을 감소시킨다 [13]. 다가 불포화 지방산은 혈중 콜레스테롤 농도를 낮추기 도 하지만 과다 섭취 할 경우, 조직의 콜레스테롤을 간으로 운반 하여 체외로 배설시켜 동맥경화를 예방 하는 것으로 알 려진 고밀도 지질 단백질 콜레스테롤(high density lipoprotein cholesterol, HDL-C)의 농도를 낮추므로 제한적 섭 취가 요구된다[14]. 이러한 다가 불포화 지방산의 대표적인 경우가 트랜스 형의 불포화지방산(trans-unsaturated fatty acid) 인데, 트랜스지방이 많이 함유된 식품으로는 마가린, 케이크, 쿠키, 전자레인지용 팝콘 등이 있다. 이러한 지방산 을 과량 섭취하면 혈액내의 HDL-C을 파괴 할 뿐만 아니라 저밀도지질단백질콜레스테롤(low density lipoprotein cholesterol, LDL-C)을 생성 한다고 알려져 혈액 내에서 LDL-C 의 수준이 높을 경우, 여러 가지 질환을 유발할 수 있지만, HDL-C이 높다면 유해한 성분을 제거하여 건강한 상태를 유 지하게 하는 것으로 알려져 있다[1].

본 연구는 현재사회의 중요한 화두가 되고 있는 트랜스 지 
방산 및 기타 지방산의 섭취가 혈관계 질환 유발 가능성의 지표인 혈중 콜레스테롤 농도, 중성 지방 농도 변화에 미치는 영향을 동물 모델을 대상으로 살펴보았다. 이를 위해 포화지 방산, 불포화지방산, 트랜스지방산이 포함된 식품을 사료에 섞어 섭취하게 한 뒤 혈중 지질 농도를 측정하였고, 특히, 트랜 스 지방 함유식품의 농도를 달리하여 섭취량에 따른 각종 혈 중 지방농도변화와 이를 바탕으로 동맥경화지표를 계산하여 나타내었다.

\section{재료 및 방법}

\section{실험동물 및 사육조건}

실험에 이용한 동물은 ICR mice (수컷, 8 주령)로 18 마리를 임의로 6집단으로 나누어 일반 고형사료로 2 일 동안 환경(온 도 $22 \pm 2^{\circ} \mathrm{C}$, 습도 $50 \sim 60 \%$ )에 적응 시킨 후 7일 동안 사육하였으 며 명암의주기는 12 시간 간격으로 조정하였다. 트랜스 불포화 지방산으로는 옥수수 마아가린(O사, 트랜스 불포화 지방산 $2.16 \%$ 함유), 포화 지방산으로는 버터( $\mathrm{S}$ 사, 포화지방산 $69.66 \%$ 함유), 불포화 지방산으로는 식용유( $\mathrm{H}$ 사, 불포화지방산 $82.06 \%$ 함유)를 녹여 사료에 첨가하는 방식으로 공급하였다. 기본식이로는 (주)중앙실험동물(Seoul, Korea) 에서 판매하는 $\mathrm{AIN}-76 \mathrm{~A}$ 을 사용하였다. 실험에는 대조군과, 포화지방산함유 군, 불포화지방산함유군, 트랜스지방산의 함량을 다르게 한 3 개군 등 총 6 개 군으로 분류하여 대조군(C), 트랜스지방산 $10 \%$ 군(TFA-1), 트랜스 지방산 30\%군(TFA-2), 트랜스 지방산 $50 \%$ 군(TFA-3), 포화 지방산 $50 \%$ 군(SFA), 불포화 지방산 $50 \%$ 군(USFA) 으로 나누어 먹이와 실험식이를 급여하였다.

\section{체중의 측정 및 혈액의 채취}

포화 지방산, 불포화 지방산, 트랜스 지방산을 함량 별로 섞은 사료로 사육한 흰쥐는 7일 동안 총 4 번 체중을 측정 하였 고, 희생 전 16 시간 동안 절식한 뒤, sodium pentobarbital (50 $\mathrm{mg} / \mathrm{kg}$ )로 마취하였다. 심장에서 채혈한 혈액은 30 분 동안 실 온에서 방치하여 응고시킨 다음, $3,000 \mathrm{rpm}$ 에서 10 분간 원심 분리하여 혈청을 취하였으며 이를 heparin이 coating된 튜브 에 넣어 $-70^{\circ} \mathrm{C}$ 에서 보존하면서 분석하였다.

\section{혈중 지질농도의 측정}

혈청 중 총 콜레스테롤(total cholesterol), 중성지질 (triglyceride) 및 HDL-C 농도는FUJI DRY-CHEM 3500i kits (FUJI FILM, Japan)를 사용하여 효소 비색법(enzymatic colormetric method)으로 분석하였고, LDL-C와 동맥경화지표는 측정된 수치를 바탕으로 계산을 통해 얻었다. LDL-C는 Friedwald 공식[3]을 이용하여 계산하였고 [(total cholesterol)(HDL-cholesterol)-(triglyceride/5)], 동맥경화지표(atherogenic index: AI)는 Haqlund등[5]의 방법에 따라 total-C에 HDL-C
의 함량을 뺀 후 다시 HDL-C로 나누어 계산하였다. 또한, Lauer 등[11]의 방법에 따라 HDL-cholesterol/total cholesterol의 비를 HTR로 나타내었다.

\section{LDL-cholesterol}

$=($ total cholesterol)-(HDL-cholesterol)-(triglyceride/5)

AI (Atherogenic index) value $=$ (total cholesterol-HDL cholesterol)/HDL cholesterol

HTR (HDL-cholesterol/total cholesterol ratio) (\%)

$=($ HDL-cholesterol $/$ total-cholesterol $) \times 100$

\section{통계처리}

통계분석은 mean $\pm \mathrm{S} . \mathrm{D}$ 로 표시하였고, $\mathrm{ANOVA}$ 에 의해 분 석 하였다. 통계적 유의성은 $p \leq 0.05$ 로 판정 하였다.

\section{결과 및 고찰}

다양한 종류의 지방산을 함유한 사료를 먹인 흰 쥐의 체중 을 비교한 결과, Fig. 1 과 같이 모든 집단에서 시간이 지날수록 체중이 증가하는 경향을 나타냈고, 일반식이를 한 대조군에 비하여 여러가지 지방산을 섞은 사료를 섭취한 집단의 체중이 높게 나타났다. 초기 체중은 $33.3 \pm 0.3 \mathrm{~g}$ 이었으나 각 지방산을 섞은 사료를 섭취한 후 각각 2.3 에서 $4.6 \mathrm{~g}$ 의 증가를 보였다. 특히, $50 \%$ trans-unsaturated fatty acid를 식이한 군의 경우, $13.7 \%$ 의 높은 증체율을 보였으며, 이는 saturated fatty acid를 섭취한 군의 증가율과 비슷하였다. 반면, $10 \%$ 의 trans-unsaturated fatty acid를 섭취한 군은 일반 식이를 섭취한 대조 군과 비교하여 정상적인 주령에 따른 증가율을 보였다. 이는 트랜스 지방산을 많이 섭취할수록 체중 증가량이 높은 것을 나타내었다.

각 실험 집단별 혈중 총 콜레스테롤 농도는 Fig. 2A에 나타 난 것처럼 대조군에 비하여 TFA-3 군과 SFA 군에서 높게 나타 났다. 특히, 트랜스 지방을 섭취한 집단에서, 섭취한 트랜스 지방함량이 높을수록 혈중 총 콜레스테롤 농도가 높게 나타나 는 것을 볼 수 있는데 이는 트랜스 지방산을 대량 섭취할수록 saturated fatty acid를 섭취하는 효과와 유사하게 나타났다. 총 콜레스테롤은 대조군에 비해 TFA-3의 경우 $19.0 \%, \mathrm{SFA}$ 군 은 $56.7 \%$ 의 증가를 보였다(Fig. 2A).

대조군과 각 지방산을 섭취한 군 간의 HDL-C의 농도에서 는 의미있는 차이를 관찰할 수 없었지만, 총 cholesterol 중 HDL-C이 차지하는 비율을 나타낸 HTR의 결과는 Fig. $2 B$ 와 같다. 총 cholesterol에서 유의적 증가를 보인TFA-3과 SFA 군 에서 HTR 역시 유의적인 감소를 보여, 혈액 내 지방 및 콜레스 테롤을 운반하는 역할을 하는 HDL-C의 양이 상대적으로 적 음을 나타내며 이 결과로 인해 포화지방산이 함유된 식이를 섭취하면 체내 cholesterol 중 HDL-C양이 줄고, 상대적으로 


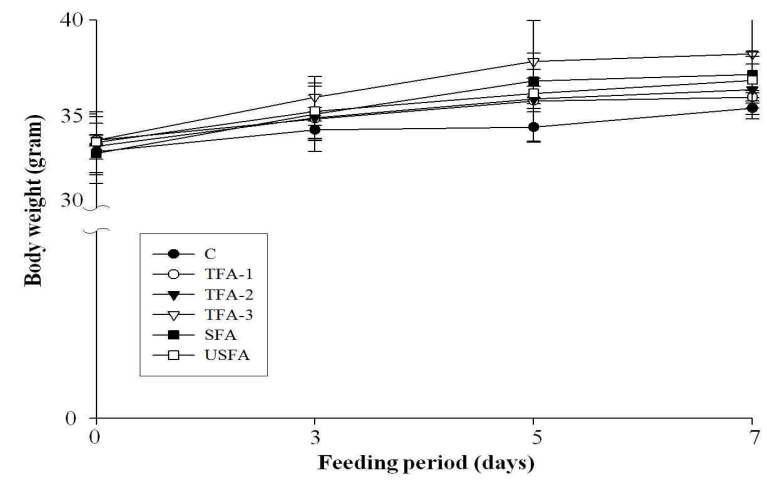

\begin{tabular}{lccc}
\hline Groups & $\begin{array}{c}\text { Initial } \\
\text { weight }(\mathrm{g})\end{array}$ & $\begin{array}{c}\text { Final } \\
\text { weight }(\mathrm{g})\end{array}$ & $\begin{array}{c}\text { Rate of body } \\
\text { weight gain }(\%)\end{array}$ \\
\hline C & $33.0 \pm 0.4$ & $35.3 \pm 0.6$ & 7.0 \\
TFA-1 & $33.6 \pm 0.3$ & $35.9 \pm 0.3$ & 6.8 \\
TFA-2 & $33.3 \pm 1.6$ & $36.3 \pm 1.3$ & 9.0 \\
TFA-3 & $33.6 \pm 0.3$ & $38.2 \pm 2.5$ & 13.7 \\
SFA & $32.9 \pm 1.6$ & $37.1 \pm 1.0$ & 12.8 \\
USFA & $33.5 \pm 1.6$ & $36.8 \pm 1.5$ & 9.9 \\
\hline
\end{tabular}

Fig. 1. Body weight gain in mouse fed with trans-unsaturated fatty acid, general unsaturated fatty acid and saturated fatty acid. C: normal diet, TFA-1: 10\% trans-unsaturated fatty acid, TFA-2: 30\% trans-unsaturated fatty acid, TFA-3: 50\% trans-unsaturated fatty acid, SFA: 50\% saturated fatty acid, USFA: 50\% general unsaturated fatty acid.

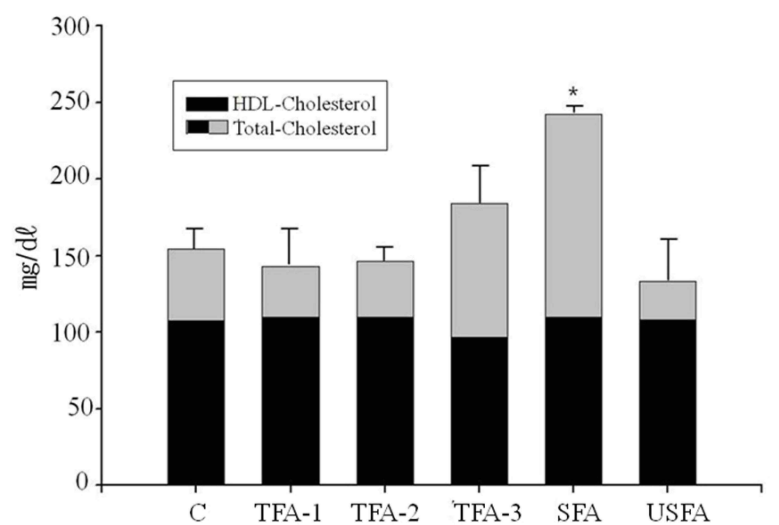

(A)

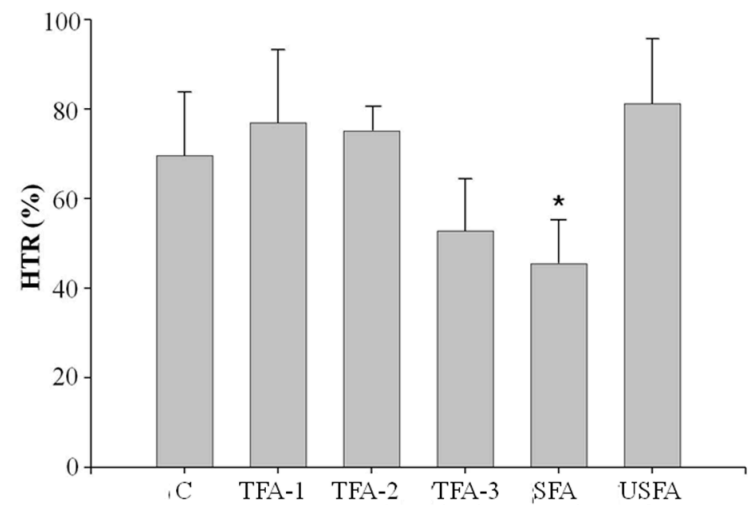

(B)

Fig. 2. (A) Concentration of serum total cholesterol and HDL-cholesterol in mice fed with trans-unsaturated fatty acid, general unsaturated fatty acid and saturated fatty acid. (B) HTR $(\%)=($ HDL-cholesterol/Total-cholesterol $) \times 100$. C: normal diet, TFA-1: 10\% trans-unsaturated fatty acid, TFA-2: 30\% trans-unsaturated fatty acid, TFA-3: 50\% trans-unsaturated fatty acid, SFA: $50 \%$ saturated fatty acid , USFA: 50\% general unsaturated fatty acid. Black bar: HDL-Cholesterol, Black and gray bar: Total cholesterol. Values are mean \pm SD for $n=3$, "Significantly different from Control group at $p<0.05$ by ANOVA, Significantly different from Control group at $p<0.01$ by ANOVA, ${ }^{* * *}$ Significantly different from Control group at $p<0.001$ by ANOVA

LDL-C이 늘어 동맥 경화와 같은 질환에 노출될 수 있음을 확인하였다. 또한 trans-unsaturated fatty acid의 함량이 높아 질수록 HTR이 감소하는 것을 관찰하였다.

혈중 triglyceride 농도는 Table 1과 같이 나타나 혈중 총 cholesterol 농도와 비슷한 경향을 보였으며 특히, TFA-3군과 SFA 군이 대조군에 비하여 각각 $29.1 \%, 19.7 \%$ 의 유의성 있는 증가를 나타냈다. 반면, general unsaturated fatty acid를 섭취 한 군과 $10,30 \%$ 의 비교적 낮은 함량의 트랜스 지방산을 함유 한 식이를 한 군은 대조군과 유사한 triglyceride의 수치를 나 타내어 낮은 함량의 트랜스 지방산을 일주일 기간 동안 섭취 한 경우에는 혈중 지질 농도에 영향을 미치지 않은 것으로 사료된다.

앞에서 측정한 각 실험집단의 혈중 총 콜레스테롤 농도, 혈
중 중성지방 농도, 혈중 HDL-C 농도를 이용하여 LDL-C 농도 를 계산한 결과 Table 1 과 같았다. TFA-3군의 경우, 대조군에 비해 $130.4 \%, \mathrm{SFA}$ 군은 $312.3 \%$ 가 증가하였고, 반면에, USFA 군 은 $75 \%$ 정도 감소하는 것을 확인하였다. 저 함량의 트랜스 지방산을 섭취한 집단은 LDL-C의 증가를 보이지 않았으며, 이는 실험기간 동안 $10,30 \%$ 의 트랜스 지방산이 혈중 LDL-C 의 농도에 영향을 미치지 않은 것으로 보여진다.

또한, Haglund등[5]의 방법에 따라 혈중 총 콜레스테롤 농 도와 혈중 $\mathrm{HDL}-\mathrm{C}$ 농도를 이용하여 동맥경화지표(AI)를 계산 한 결과 Fig. 3과 같이 나타났고, LDL-C함량과 유사한 결과를 보였다. 즉, TFA-3군에서 $205.5 \%, \mathrm{SFA}$ 군에서 $275.6 \%$ 의 증가를 보였으며, USFA군은 $50 \%$ 정도 감소하였다. 이는 trans-unsaturated fatty acid를 장기적으로 대량 섭취했을 경우 동맥경 
Table 1. Lipid levels gain in mouse fed trans-saturated fatty acid, general saturated fatty acid and saturated fatty acid

\begin{tabular}{ccc}
\hline \multirow{2}{*}{ Groups $^{1)}$} & \multicolumn{2}{c}{ Concentration $(\mathrm{mg} / \mathrm{dl})$} \\
\cline { 2 - 3 } & $\mathrm{TG}^{2}$ & LDL-C $^{3)}$ \\
\hline Control & $105.1 \pm 28.6$ & $26.3 \pm 1.8$ \\
TFA-1 & $92.3 \pm 25.5$ & $14.6 \pm 1.7^{* *}$ \\
TFA-2 & $83.7 \pm 24.8^{*}$ & $19.7 \pm 1.0$ \\
TFA-3 & $135.5 \pm 48.8^{* * *}$ & $60.0 \pm 3.2^{* * *}$ \\
SFA & $125.7 \pm 24.5^{*}$ & $107.2 \pm 4.4^{* * *}$ \\
USFA & $90.0 \pm 52.2$ & $7.9 \pm 0.6^{* * * *}$ \\
\hline
\end{tabular}

${ }^{1)} \mathrm{C}$ : normal diet, TFA-1: $10 \%$ trans-unsaturated fatty acid, TFA-2: 30\% trans-unsaturated fatty acid, TFA-3: 50\% trans-unsaturated fatty acid, SFA: 50\% saturated fatty acid, USFA: 50\% general unsaturated fatty acid

${ }^{2)}$ TG: triglyceride

${ }^{3}$ LDL-C: low-density lipoprotein cholesterol, LDL-cholesterol $=($ total cholesterol $)-($ HDL-cholesterol $)-($ triglyceride $/ 5)$

*Significantly different from Control group at $p<0.05$ by ANOVA

"Significantly different from Control group at $p<0.01$ by ANOVA

Significantly different from Control group at $p<0.001$ by ANOVA

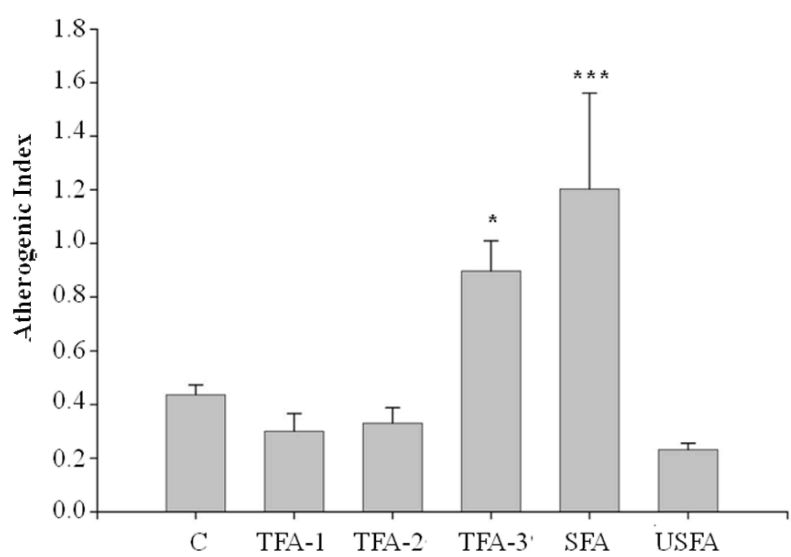

Fig. 3. Atherogenic index (AI) gain in mice fed with trans-unsaturated fatty acid, general unsaturated fatty acid and saturated fatty acid. C: normal diet, TFA-1: 10\% trans-unsaturated fatty acid, TFA-2: $30 \%$ trans-unsaturated fatty acid, TFA-3: 50\% trans-unsaturated fatty acid, SFA: 50\% saturated fatty acid, USFA: 50\% general unsaturated fatty acid. AI value $=$ (Total cholesterol-HDL cholesterol)/HDL cholesterol. Values are mean \pm SD for $\mathrm{n}=3$, "Significantly different from Control group at $p<0.05$ by ANOVA, "Nignificantly different from Control group at $p<0.01$ by ANOVA, ${ }^{\text {"** }}$ Significantly different from Control group at $p<0.001$ by ANOVA

화와 같은 심혈관계 질환이 발병될 확률이 높아진다는 것을 의미하였다.
일주일간 생쥐에게 general unsaturated fatty acid, saturated fatty acid, trans-unsaturated fatty acid의 다양한 종류의 각 지방산을 함유하고 있는 식품을 사료에 섞어 식이 하였으 며, 희생하여 mice의 혈중 지질 농도를 측정하였다. 그 결과, 트랜스 지방이 많이 함유된 사료를 섭취한 집단일수록 체중이 나 혈중 총 콜레스테롤 농도, 혈중 LDL-C 농도, 동맥경화지표 가 높게 나타났으나, 혈중 HDL-C 농도는 변화가 없었다. 포화 지방산 다량 함유된 먹이를 섭취한 집단에서 체중이나 혈중 총 콜레스테롤 농도, 혈중 중성지방 농도, 혈중 LDL-C 농도, 동맥경화지표가 높게 나타나며, 불포화 지방산이 다량 함유된 먹이를 섭취한 집단에서는 대체로 체중을 비롯한 혈중 총 콜 레스테롤 농도, 혈중 중성지방농도, 혈중 LDL-C 농도, 동맥경 화지표가 낮게 나타났다. 본 실험의 경우, 소수의 생쥐를 대상 으로 짧은 기간 실험한 것으로 추가적인 실험을 통해 trans형 불포화 지방산이 혈중 지질 농도에 대한 자세한 기작을 설명 해야 할 것이다.

따라서 본 실험결과를 통해 트랜스지방이 다량 함유된 패스 트푸드나 인스턴트 식품을 섭취하게 될 경우에는 체내 혈액 속의 각종 지질농도가 증가하게 되므로 동맥경화, 고지혈증, 심근경색 등의 각종 혈관계 질환이 발병할 확률이 높아질 것 이라는 것을 알 수 있었다. 또한, 소량의 트랜스 지방 함유 식품을 장기간 섭취 할 경우에도, 혈중 지질 농도에 악 영향을 미칠 것으로 예측된다. 그러므로 가능한 한 트랜스지방의 함 유 정도가 낮은 식품을 섭취하는 식습관을 갖도록 하여 혈관 계 질환을 예방할 수 있도록 권장하여야 할 것이다.

기존 연구에서 트랜스 지방의 섭취는 혈관계의 초기면역반 응을 유도 하는 것으로 보고되었다[2]. 혈관계에 미치는 영향 을 알아보기 위하여 human aortic endothelial cells (HAECs) 에 트랜스 지방을 처리하여 mRNA level을 확인한 결과 ROS 와 NF-kB의 생산을 촉진하였다. 이는 Harvey [6,7]의 연구에 서도 확인 할 수 있다. 트랜스 지방의 섭취로 인하여 혈관계에 초기 면역반응이 유도 되며 심혈관계 질환의 위험도가 높아 지는 것이다.

또한 최근 트랜스 지방이 함유된 식품이 각종 성인병의 원 인으로 밝혀지면서 식품 제조업체 등에서는 각종 식품 제조에 사용하던 마아가린, 쇼트닝 등의 트랜스 지방을 대체하여 버 터나 팜유 등의 포화 지방이 다량 함유된 지방을 이용해 식품 을 제조하는 업체가 늘어나고 있다. 하지만 본 실험결과로 미 루어 볼 때 포화지방산이 다량 함유된 음식을 섭취 하였을 때가 트랜스 지방이 함유된 음식을 섭취하였을 경우보다 오히 려 각종 혈액 속의 각종 콜레스테롤 농도가 높아짐을 알 수 있었다. 최근 이와 관련하여 보고된 Yang의 연구[15]는 수컷 Wistar rat에 saturated/monounsaturated/polyunsaturated $(\mathrm{S} / \mathrm{M} / \mathrm{P})$ fatty acid의 비율을 다르게 식이 하여 각 혈청의 지 질농도와 adiponectin의 mRNA level을 확인하였다. 그 결과, saturated fatty acid의 함량이 상대적으로 높은 2:1.5:1 group 
에서 total cholesterol, LDL-cholesterol과 glucose의 수치가 높 게 나왔으며, S/M/P 1:1:1, 1:1:2 group에서 triglyceride의 수 치가 낮았으며 HDL-cholesterol의 수치가 유의성 있게 증가 함을 나타냈다. 그리고 adiponectin의 mRNA 발현 정도가 낮 아짐을 확인하였다. 이는 다양한 fatty acid의 각 비율이 glucose와 lipid metabolism의 조절과 adiponectin의 발현에 중요 한 역할을 한다는 것을 나타내고, 특히, saturated fatty acid의 함량이 중요 하다는 것을 말하며, 본 실험에서도 이 결과를 확인 할 수 있었다

따라서, 이상의 결과에서 체내에 악영향을 미치는 포화지방 산의 섭취량을 줄이도록 해야 하며, 불포화 지방산 중에서도 다가 불포화 지방산, 특히, 트랜스 지방의 섭취에 주의를 기울 이는 것이 건강한 식습관을 유지할 수 있을 것이라 사료 된다. 또한 각 식품 제조업체의 포화 지방산과 트랜스 지방 함유량 에 따른 적정 수준의 제도적 장치가 마련되도록 노력해야 할 것이다.

\section{감사의 글}

본 연구는 Women Into Science Engineering (WISE) 부산/ 경남 지역센터의 지원을 받아 수행되었습니다.

\section{References}

1. Bose, K. S. and Agrawal, B. K. 2007 Effect of lycopene from cooked tomatoes on serum antioxidant enzymes, lipid peroxidation rate and lipid profile in coronary heart disease. Singapore Med J. 48, 415-420.

2. Bryk, D., Zapolska-Downar, D., Malecki, M., Hajdukiewicz, K. and Sitkiewicz, D. 2011. Trans fatty acids induce a proinflammatory response in endothelial cells through ROS-dependent nuclear factor- $\mathrm{kB}$ activation. J. Phusiol. Pharmacol. 62, 229-238

3. Friedwald, W., Levy, R. and Fredrickson, D., 1972. Estimation of the concentration of low-density lipoprotein cholesterol in plasma, without use of the preparative ultracentrifuge. Clin. Chem 18, 499-502.

4. Garcia, G., Sunil, T. S. and Hinojosa, P. 2012. The fast food and obesity link: consumption patterns and severity of obesity. Obes. Surg. 22, 810-818.

5. Haqlund, O., Luostarinen, R., Wallin, R., Wibell, L. and
Saldeen, T. 1991. The effects of fish oil on triglycerides, cholesterol, fibrinogen and malondialdehyde in humans supplemented with vitamin E. J. Nutr. 121, 165-169.

6. Harvey, K., A., Arnold, T., Rasool, T., Antalis, C., Miller, S. J. and Siddiqui, R. A. 2008. Trans-fatty acids induce pro-inflammatory responses and endothelial cell dysfunction. Br. J. Nutr. 99, 723-731.

7. Harvey, K. A., Walker, C. L., Xu, Z., Whitley, P. and Siddiqui, R. A. 2012. Trans Fatty Acids: Induction of a Pro-inflammatory Phenotype in Endothelial Cells. Lipids 47, 647-657.

8. Hickson, D. A., Diez Roux, A. V., Smith, A. E., Tucker, K. L., Gore, L., D., Zhang, L. and Wyatt, S. B. 2011. Associations of fast food restaurant availability with dietary intake and weight among African Americans in the Jackson Heart Study, 2000-2004. Am J. Public. Health 101 Suppl 1, S301-S309.

9. Hill-Pryor, C. and Dunbar, J. C. 2006. The effects of high fat-induced obesity on cardiovascular and physical activity and opioid responsiveness in conscious rats. Clin. Exp. Hypertens 28, 133-145.

10. Jensen, J., Bysted, A., Dawids, S., Hermansen, K. and Holmer, G. 1999. The effect of palm oil, lard, and puff-pastry margarine on postprandial lipid and hormone responses in normal-weight and obese young women. Br. J. Nutr. 82, 469-479.

11. Lauer, R. M., Lee, J. and Clarke, W. R. 1988 Factors affecting the relationship between childhood and adult cholesterol levels: the Muscatine Study. Pediatrics 82, 309-318.

12. Popkin, B. M., Adair, L. S. and Nq, S. W. 2012. Global nutrition transition and the pandemic of obesity in developing countries. Nutr. Rev. 70, 3-21.

13. Strom, M., Halldorsson, T. I., Mortensen, E. L., Torp-Pedersen, C. and Olsen, S. F. 2012. Fish, n-3 fatty acids, and cardiovascular diseases in women of reproductive age: a prospective study in a large national cohort. Hypertension $59,36-43$

14. Wilson, M. D. and Rudel, L. L. 1994. Review of cholesterol absorption with emphasis on dietary and biliary cholesterol. J. Lipid Res. 35, 943-955.

15. Yang, X., Zhang, Y., Lin, J., Pen, A., Ying, C., Cao, W. and Mao, L. 2012. A lower proportion of dietary satu$\mathrm{rated} /$ monounsaturated/polyunsaturated fatty acids reduces the expression of adiponectin in rats fed a high-fat diet. Nutr. Res. 32, 285-291. 


\section{초록 : 트랜스형 불포화 지방산이 mice 혈중 지질농도에 미치는 영향}

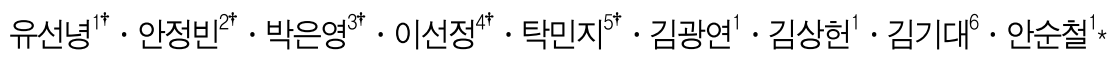

( ${ }^{1}$ 부산대학교 의학전문대학원 미생물학 및 면역학교실, ${ }^{2}$ 울산과학기술대학교 나노생명화학공학부, ${ }^{3}$ 부경대 학교 공과대학 화학공학과, ${ }^{4}$ 부산가톨릭대학교 보건과학대학 병원경영학과, ${ }^{5}$ 성균관대학교 생명공학대학 유전공학과, ${ }^{6}$ 동래여자고등학교)

본 연구에서는 각기 다른 형태의 지방산이 ICR mice의 혈중 지질 농도에 미치는 영향을 평가하고자 하였다. 이를 위하여 8 주령 수컷 ICR mice를 일반 식이섭취군(C), $10 \%$ 의 트랜스 불포화 지방산 섭취군(TFA-1), $30 \%$ 트랜 스 불포화 지방산 섭취군(TFA-2), $50 \%$ 트랜스 불포화 지방산 섭취군(TFA-3), $50 \%$ 포화 지방산 섭취군(SFA), 불포 화 지방산 섭취군(USFA) 으로 나누어 식이 하였다. 혈중 총 콜레스테롤의 수치는 TFA-3 군과 SFA 군의 지질 함량이 다른 군에 비하여 높았으며, 중성지방지수 역시 높게 나타났다. 총 콜레스테롤과 중성지방수치를 이용하 여 나타낸 LDL 콜레스테롤의 경우에도 $50 \%$ 의 트랜스 지방산을 섭취한 군에서 포화 지방산을 섭취한 군과 유사 한 결과가 나타났다. 이에 반해, $10 \%, 30 \%$ 의 트랜스 지방산을 섭취한 군에서는 일반식이 섭취군과 비슷한 결과가 나타났다. 이는 많은 양의 트랜스 불포화지방산을 짧은 기간 동안 섭취하더라도 포화지방산을 섭취한 것과 유사 한 효과를 나타낸다는 것을 의미한다. 